\title{
The Position of Crime Resolution Institutions in Indige- nous Peoples in the Identity Politics Perspective
}

\author{
Blasius Mau Kau, Hari Sutra Disemadi* and Yusriadi \\ Faculty of Law, Diponegoro University, Semarang \\ Email: haridisemadi@gmail.com
}

\begin{tabular}{|l|}
\hline \multicolumn{1}{|c|}{ Published: 15/09/2020 } \\
\hline How to cite (in APA style): \\
$\begin{array}{l}\text { Kau, B, M., Disemadi, H, S., Yusriadi, Y. (2020). The Position of Crime Resolution Institutions in Indigenous Peoples in } \\
\text { the Identity Politics Perspective. Jurnal Hukum Prasada, 7(2), 79-84. doi: https://doi.org/10.22225/jhp.7.2.1224.79-84 }\end{array}$ \\
\hline
\end{tabular}

\begin{abstract}
One of the demands is to disregard modern justice institutions and utilize customary law as a means to achieve justice for those involved in a criminal offense. But on the other hand, the settlement of the case with customary law turned out to still cause injustice to the victim, and even gave birth to new crimes arising as a result of coercion carried out by the customary leaders of both parties acting as judges. This study discussed about the position of crime resolution institutions in indigenous peoples in the perspective of identity politics and the reassessing the position of crime resolution institutions in indigenous peoples, certainly cannot be separated from the recognition of identity with all the structures and positions of indigenous peoples themselves. This study was designed by using normative legal research approach. The results show that efforts to reassess the position of crime resolution institutions in indigenous peoples, of course, cannot be separated from the recognition of identity with all the structures and positions of indigenous peoples themselves. However, the dominance arising from the resolution of indigenous peoples' crimes is still determined by cultures that are patriarchal, rigid and as if forced from above so as to ignore dialogue both from perpetrators and victims, so that the measure used is the perspective of tribal leaders. However, domination is believed to restore order, order and harmony, but there is one neglected value of ethical legitimacy, namely justice. Therefore, the resolution of crimes against indigenous peoples does not all distribute justice to all parties.
\end{abstract}

Keywords: Consumer Protection; Criminal Law; Islam Economic Law

\section{INTRODUCTION}

One of cultural politics is identity politics, namely the recognition of the equality of different cultural values as the basis for the particularity needed for unconditional acceptance. In the sense of acceptance contained in the affirmation of ethnic particularity which contains a variety of potential values so that it can be used as a benchmark for building indigenous hegemony based on existing value culture entities (Anjari, 2014). Each culture has the freedom to choose values that are according to his will, what he sees as the right way. While the problem that often arises is that someone often uses his belief to see other people.

Paul F. Knitter stated that everyone has their own telescope, which presents their culture or religion to see and observe others (Hidayati, 2008). There is recognition of individual identity and there is recognition of cultural group identity. Individual identity is particular. What is important is the recognition of cultural identity because this recognition is a vital need. Identity recognition focuses on differences in identity which include ethnicity, religion, race and others that are used to gather people on the basis of similarity (Abubakar, 2013).

But the recognition of identity is also included with existing norms in indigenous 
peoples as a benchmark for maintaining order and order. On this basis, the existence of traditional institutions is very much needed and as a necessity to get recognition from indigenous peoples themselves (Gahral, 2006). Because the existence of an indigenous community is inseparable from recognition both from the outside and from within the community itself, so that trust in values, norms that live in indigenous peoples are not based on compulsion, but are based on a given, given factor this is what causes the strengthening of indigenous peoples with all forms of wisdom (Budianto, 2016).

\section{METHOD}

The research method used in this study is doctrinal, that is, using normative legal research. The specification of this study is descriptive analytical, which describes the problems of the object under study and a number of factors that affect the data obtained are collected, compiled, explained, then analyzed and finally concluded. The data used in this research are obtained from secondary data, namely data obtained indirectly from the source, in the form of: 1). Primary legal material, namely legal materials that have juridical binding power; 2).Secondary legal material, namely legal material that provides an explanation of primary legal materials such as books, magazine and newspaper articles, internet articles, and papers related to the topic of this writing; and 3). Tertiary legal material, namely legal material that provides an explanation of primary legal material and secondary legal material because the legal materials can clarify an issue or a term found in primary and secondary legal materials such as legal dictionaries and other language dictionaries. After collecting the data, then those data were analysed by using descriptive qualitative method and were presented in paragraph through words.

\section{DISCUSSION}

\section{Recognition of Indigenous Peoples as One of Cultural Politics}

One cultural politics is identity politics, namely the recognition of the equality of different cultural values as the universal basis needed for unconditional acceptance. In the sense of acceptance contained in the affirmation of ethnic particularity which contains the potential of universal values that can be shared with others (Abubakar, 2013). Identity politics shows an expression of the complexity of human needs for feelings of belonging (Gahral, 2006). Identity politics can be defined as political actions to prioritize the interests of members of a group because they have the same identity or characteristics, whether based on race, ethnicity, gender, or religion.

However, the entity of indigenous peoples in their position as community, as defined by Van Vollenhoven, is a legal society characterized by the notions of human unity that has an orderly arrangement, a fixed area, and has leadership with all limited structures, and possess assets, tangible assets (land, heirlooms), as well as intangible assets (titles of nobility) (Kamaruddin, 2013). It is this attachment model that shapes indigenous peoples with all forms of their life, both closed and following a dynamic of life that leads to changes caused by the flow of globalization. But in responding to all forms of change, the values that are held increasingly strengthen. So that each indigenous group demands that it be recognized as a cultural identity to grow unique and different in the political system of open democracy, especially in the country's political system (Abubakar, 2013).

\section{Politics Recognition of Important Aspects in Building the Identity of Indigenous Peoples}

According to Taylor, democracy has delivered a policy of equal recognition which has taken various forms throughout history, and has now returned in the form of demands for the equal status of cultures (Guttman, 1994).

In politics of human dignity, every human being has similarities that must be respected and must be recognized. This similarity is revealed in the same rights and freedoms as stated in the catalog of human rights as reflected in every culture. Taylor Sediri emphasizes the importance of the aspect of recognition from others in building identity, both individual and group identity. Only in its uniqueness, humans can be themselves. Therefore, there is now a demand for recognition, namely the recognition of 
differences in the values of cultures in indigenous peoples which must be protected in a state's existence. Because each indigenous tribe has a contribution in the formation of national law.

The culture of indigenous peoples as a value system must be recognized and how small a community is, it requires recognition of its cultural values. Because culture is given, and there are people who want to live as unique. The demand for the recognition of culture has a basis, because culture has its roots that stick out in every community, especially indigenous peoples (Harahap, 2018). If there is another culture that enters (transcultural), there must be an interest and there is a fear that the values of culture given will become extinct. The solution is recognition of cultural values in order to survive. However, each indigenous community has a rule model to maintain the existing value system, even has its own judicial mechanism to resolve crimes so that harmony and integrity are maintained even though the application system in resolving crime can be very paternalistic, deterministic and even repressive depending on the interaction pattern.

\section{Review the Crime Resolution that Happens in Indigenous Peoples}

The existence of legal pluralism in the unitary state of the Republic of Indonesia has led to differences in the sense of justice according to criminal law and customary criminal law. The meaning of legal pluralism that occurs in each indigenous community provides optics to examine each crime and how to resolve crimes differently, depending on the structure and position of the local indigenous people (Suartha, 2015), of course, it does not mean that indigenous peoples have almost the same definition of what crime is, but to revolutionize crime that occurs in indigenous peoples is very different and may not necessarily create a sense of justice for all parties, including perpetrators of crime.

The assumptions that underlie that the settlement of criminal cases through the old, expensive and seemingly criminal justice system are not able to restore a relationship that has been broken due to a criminal act raises criticism by offering a way of settlement which is seen as more bringing justice (Tamarasari, 2002). One of the demands is to provide as much space as possible so that customary law is used as a means to achieve justice for those involved in a crime. But there is something that is forgotten that in every indigenous / traditional society still holds tightly to the paternalistic culture that is so thick, it even dominates in taking all policies including resolving crime.

\section{What is the Perspective of Indigenous Peoples to Resolve Crime?}

Every indigenous community has a very unique perspective to solve every crime, both minor crimes and crimes that are considered severe. But there is one similarity that then emerges that policies to resolve crime are a strategy to arouse / raise the spirit or the soul of the human being and attempt to reinforce the belief that is damaged by a crime, therefore stability and harmony need to be restored so that integrity is maintained (Astuti, 2015). This type of crime resolution is more emphasized in the integrity of the community. So customary justice is strong in nature or in the mind of communalism and religiuousmagical (cosmic), namely the most important consideration in resolving crime is communal stability and wholeness, not because of the issue of justice that is intended or the human rights perspective is a priority (Soepomo, 1967).

The model of crime resolution presented by indigenous peoples like this is not much different from the conventional national justice system, where the criminal is applied to punish the perpetrators and on the other hand restore the stability resulting from the crime (Simarmata, 2006), so that the victims of the crime caused are not covered by good, the consequence is that justice cannot be achieved by victims and material and immaterial losses in human rights nuances are ignored. This is what needs to be taken into account by indigenous peoples in resolving crime in order to restore all parties based on equality and justice (Astuti, 2015). If this is truly applied in restoring all parties, the belief that arises is that customary justice is able to achieve justice for all parties, but instead it is unable to restore due to paternalistic cultural problems and deterministic mechanisms, it is not yet believed that customary justice is able to achieve justice.

The Position of Victims in Resolving Crime at the Level of Indigenous Peoples 
Changes in cultural values adopted by the community, can also be formulated through the decisions of formal and informal officials who are authorized to resolve disputes that occur in the community (Arif, 2018). Decisions taken by the customary leaders may show new things that indicate that there has been a change in value. However, customary criminal law regulates actions that violate the feelings of justice and propriety that live in the community, causing disturbance to the peace and balance then the customary reaction occurs (Suartha, 2015).

A closer examination of the issue of crime resolution shows us the motive that causes the right to choose from the victim's side is actually not given the freedom to express what he experienced as a victim, so the victim's freedom space is monopolized by the tribal leader to revolutionize every crime with his main thesis wanting restore harmony (Safrijal, 2013).

In these circumstances, is it possible that the level of right to vote will endanger the peace of the people, is it possible that the injured victims are waiting in peace for their rights to be fulfilled? Is it possible that victims who have the right to convey what should be conveyed, but not given that space due to the domination of the chief are able to fulfill the demands of the victims? Such questions escape the crime resolution mechanism that exists in indigenous peoples, so the tendency to emerge is to equate the perception that justice is achieved if harmony in resolving the crime is successful. Even though the meaning of justice goes far beyond harmony and harmony that is achieved does not necessarily bring justice if the method taken is of a paternalistic nature (Ode, 2015). If the role of chieftain is limited to its proper functions, the interests of every person in the law will be the same and the resolution of crime does not have to take ownership of one person and be given to communal rights.

\section{Seeing the free will of the Judiciary of Indigenous Peoples}

Customary criminal law adheres to an open legal system, which does not recognize the distinction between violations in the field of criminal law and violations in the field of civil law (Suartha, 2015). An action might violate several legal norms at once, a means to restore legal balance, some reaction / correction actions must be taken, for example a change of loss, safety / ritual to cleanse the community of feeling dirty with the unseen. However, efforts to arrive at the level of returning harmony must be based on the free will of the party that caused the crime or victims of crime and the local indigenous people (Muladi \& Arief, 1998).

The tendency which later became the assumption that people who commit crimes or cause a disturbance in the structure of indigenous peoples will lose their free will and there is only one thing that is imposed on them, namely pasra, on what sanctions are given. There is the most important thing that is wrongly interpreted in this matter, that is free will is very important in resolving crime, not eliminated at all. Because it was the starting point of free will that revealed the cause of the crime and how it was later restored. The role of free will is very important for resolving crime in indigenous peoples, so that we know how to do evil? What kind of recognition model can be achieved for justice? And what responsibility should be accepted by the perpetrators of crime? and what kind of society wants to revolutionize crime? as well as what limits must be used optimally by the tribal chief to revolutionize crime? to answer this problem is to activate the free will of all parties to resolve crime and not free will only be owned by the chief (Saraswati, 2015).

\section{Is it True that Reconciliation Can be Achieved in the Resolution of Crimes That Exist in Indigenous Peoples?}

The term reconciliation certainly has a broad understanding impact, it is an effort to improve and create new relations oriented to peace that are undertaken by two parties that were previously or are in conflict. Even reconciliation is an interpersonal event that requires commitment from both parties to stop the conflict and the relationship that is built up in reconciliation does not only involve victims and violators, but also occurs between violators and violators (Tamarasari, 2002).

The size of the definition used in crime resolution so that reconciliation is achieved is 
of course a very textual measure. However, the use of this term must be contextual, the extent to which the mechanism used must be in accordance with the culture of indigenous peoples, the location of the social system, the pattern of interaction, the role played by tribal leaders and the extent to which the crime is viewed by the community and other aspects that influence indigenous peoples. This kind of understanding is first needed to be known in advance, and then offer a reconciliation path (Kamaruddin, 2013).

Back in the title of the discussion on reassessing the position of the resolution institutions of indigenous peoples' crime it seems difficult to create reconciliation, because the appropriateness of a reconciliation must be free from coercion, the role of domination, and avoiding all forms of recognition of paternalistic culture that is capable of presenting the truth. This attitude actually hinders the reconciliation line (Budianto, 2016). Because reconciliation presupposes the existence of an attitude of recognition of openness, humility, self-awareness and not placing oneself in social status but opening up to the recognition of equality and dignity.

\section{Ethical Legitimacy in the Process of Resolving Crime in Indigenous Peoples}

Every indigenous community has ethical legitimacy that questions the legitimacy of the authority of customary institutions that are used to solve every problem. Ethical legitimacy wants to question what kind of mechanism can be morally done to produce order (Suseno, 1987). Within this framework ethical legitimacy is understood as a demand that problems be solved according to moral principles (Safrijal, 2013). In every indigenous community moral principles are very high, even to regulate every order and order in society, enough with moral values, no written law is needed. Any action or event that does not harmonize or rape the safety of the community, class, community friends can be a violation of the law (Suartha, 2015). To assess an act contradicting customary law, its size is a moral principle.

The moral principles in indigenous peoples are very strong. As a measure used to regulate the lifestyle of indigenous peoples. But the question is whether the ethical legitimacy possessed by tribal leaders is able to resolve crime ethically? Because there are other factors that become dominant that are owned by the tribal leader who considers themselves as heirs, has great legitimacy, and thickens the thought that paternalistic culture is still considered both by the indigenous people themselves and the assumption of the tribal chief, with conditions like this do not close it is likely that the efforts used to resolve any existing crime may be absent from moral values (Budianto, 2016).

\section{CONCLUSION}

Efforts to reassess the position of crime resolution institutions in indigenous peoples, of course, cannot be separated from the recognition of identity with all the structures and positions of indigenous peoples themselves. However, the dominance arising from the resolution of indigenous peoples' crimes is still determined by cultures that are patriarchal, rigid and as if forced from above so as to ignore dialogue both from perpetrators and victims, so that the measure used is the perspective of tribal leaders. However, domination is believed to restore order, order and harmony, but there is one neglected value of ethical legitimacy, namely justice. Therefore, the resolution of crimes against indigenous peoples does not all distribute justice to all parties.

\section{REFERENCES}

Abubakar, L. (2013). Revitalisasi Hukum Adat Sebagai Sumber Hukum Dalam Membangun Sistem Hukum Indonesia. Jurnal Dinamika Hukum, 13(2), 319-331. https:// doi.org/10.20884/1.JDH.2013.13.2.213

Anjari, W. (2014). Fenomena Kekerasan sebagai Bentuk Kejahatan (Violence). E-Journal WIDYA Yustisia, 1(1), 42-51. Retrieved from https://media.neliti.com/media/publications/246968fenomena-kekerasan-sebagai-bentuk-kejaha-60c284aa.pdf

Arif, B. N. (2018). Bunga Rampai Kebijakan Hukum Pidana Perkembangan Penyusunan Konsep KUHP Baru. Semarang: Kencana Prenada media Grup.

Astuti, G. F. Y. (2015). Relevansi Hukum Pidana Adat Dalam Pembaharuan Hukum Pidana di Indonesia. Pandecta: Research Law Journal, 10(2), 195-214. https://doi.org/10.15294/ 
pandecta.v10i2.4953

Budianto, E. T. (2016). Implementasi Kebijakan Hak-Hak Masyarakat Adat (Studi Masyarakat Adat Di Kecamatan Lindu Kabupaten Sigi). Katalogis, 4(4), 137-145. Retrieved from https:// media.neliti.com/media/publications/147042-ID-implementasi-kebijakan-hak-hakmasyaraka.pdf

Gahral, A. D. (2006). Demokrasi Kami. Depok: Kokoesan.

Guttman, A. (1994). Multiculturalisme: Examining the Politicks of Recognition. New Jersey: Princeton University Press.

Harahap, A. (2018). Pembaharuan Hukum Pidana Berbasis Hukum Adat. Jurnal Edutech, 4(2), 1-9. Retrieved from http://jurnal.umsu.ac.id/index.php/edutech/article/view/2268

Hidayati, M. (2008). Jurang diantara Kita. Yogjakarta: Kanisius.

Kamaruddin, K. (2013). Model Penyelesaian Konflik di Lembaga Adat. Walisongo: Jurnal Penelitian Sosial Keagamaan, 21(1), 39-70. https://doi.org/10.21580/ws.2013.21.1.236

Muladi, \& Arief, B. N. (1998). Teori-teori dan Kebijakan Pidana. Bandung: Alumni.

Ode, S. (2015). Budaya Lokal Sebagai Media Resolusi Dan Pengendalian Konflik Di Provinsi Maluku (Kajian,Tantangan Dan Revitalisasi Budaya Pela). Politika, 6(2), 93-100. https:// doi.org/10.14710/politika.6.2.2015.93-100

Safrijal, A. (2013). Penerapan Sanksi Adat dalam Penyelesaian Perkara Pidana di Kabupaten Nagan Raya. Kanun: Jurnal IImu Hukum, 15(59), 145-162. https://doi.org/10.24815/ kanun.v15i1.6165

Saraswati, P. S. (2015). Fungsi Pidana dalam Menanggulangi Kejahatan. Jurnal Advokasi, 5(2), 139 -154. https://doi.org/10.1017/CBO9781107415324.004

Simarmata, R. (2006). Pengakuan Hukum Terhadap Masyarakat di Indonesia. Jakarta: UNDP.

Soepomo. (1967). Bab-bab Tentang Hukum Adat. Jakarta: PT. Paradya Paramita.

Suartha, I. D. M. (2015). Hukum dan sanksi Adat Perspektif Pembaharuan Hukum Pidana. Malang: Setara Press.

Suseno, F. M. (1987). Etika Politik: Prinsip-prinsip moral Dasar Kenegaraan Modern. Jakarta: Penerbit Gramedia.

Tamarasari, D. (2002). Pendekatan Hukum Adat dalam Menyelesaikan Konflik Masyarakat pada Daerah Otonom. Jurnal Kriminologi Indonesia, 2(I), 37-47. Retrieved from https:// www.neliti.com/publications/4219/pendekatan-hukum-adat-dalam-menyelesaikan-konflikmasyarakat-pada-daerah-otonom 